\title{
OPINION
}

\section{The Difficulty in Estimating the Total Population Size of Wild Elephants in Sri Lanka}

\author{
Charles Santiapillai ${ }^{1,2}$ \\ ${ }^{1}$ Adjunct/Faculty of Applied Sciences, Rajarata University of Sri Lanka, Mihintale, Sri Lanka. \\ ${ }^{2}$ Adjunct/Faculty Darr School of Agriculture, Missouri State University, Missouri, USA. \\ Accepted December 30, 2013
}

In August 2011, the Department of Wildlife Conservation (DWC) of Sri Lanka carried out the first all-island survey to assess the status of the wild elephants. People in general and wildlife enthusiasts in particular want to know just how many elephants are there in Sri Lanka. Laymen often make the mistake of assuming that given the huge size of elephants that it would be relatively easy to count them accurately in the wild. But in fact, it is more difficult to count elephants in a forest than fish in a pond. As Cynthia Moss (1988) argues, it is precisely because elephants are so large that we can miss those that are either hidden behind the bulk of some huge animals or enclosed within a herd. Even on the open grasslands of Sri Lanka where elephants can easily be observed, one may have to count a small herd several times before ascertaining the exact number (Santiapillai and Wijeyamohan, 2003).

Counting elephants in forests is not easy. In 1981, African elephant specialists agreed that there were at least 1.1 million African elephants, but speculated that there might be over 2 million more (Jackson, 1982). These estimates were not based on any rigorous method but on the results from questionnaire surveys and the considered opinions of Wildlife Wardens, Game Rangers and professional elephant hunters.

At the same time, the situation ably summarized by Uganda's one time Chief Warden, Rene Bere indicated the existence then of only about 300,000 elephants in the whole of African continent (Sikes, 1971). Subsequently, DouglasHamilton (1987) argued that from the 1970s through the 1980s, ivory poachers had reduced Africa's savanna elephants from c. 1.3 million to 500,000 . Thus, if we accept the starting estimate of African elephants to be 1.1 million, then the population had indeed declined by $55 \%$ to 500,000 . However, if we took Rene Bere's estimate of 300,000 as the starting point, Africa's elephant population has in fact increased by $67 \%$ to 500,000 . Herein lies the difficulty. We therefore need to bear in mind what Samuel Johnson said about round numbers.

The number of elephants in the island today is but a fraction of what existed about a hundred years ago (Santiapillai and Jackson, 1990). How numerous elephants were at one time can be appreciated by a reference to the numbers captured or killed. In 1828 a law was passed prohibiting the capture of elephants except on behalf of the government, but the law was rescinded in 1831 (Nicholas, 1954). Until then elephants were so plentiful that the Government not only encouraged their destruction (Storey, 1907), but also paid rewards for any that was killed (Baker, 1853). It was at this time shooting of elephants became a fashionable sport among the European gentry. Elephants could still be shot near Colombo in 1849 (Deraniyagala, 1955). A total of 3,500 elephants were shot in the three years up to 1848 in the Northern Province, while in the Southern Province, 2,000 elephants were killed in the four years up to 1855 (Olivier, 1978). Thus, more than 5,000 elephants were eliminated systematically within a period of just 10 years (Tennent, 1867). Major Thomas William Rogers is reputed to have killed some 1,400 elephants during a 11 year period from 1834 to 1845 ; another Captain Gallway has the credit of slaying more than half that number, and Major Skinner, the Commissioner of Roads, almost as many according to Nicholas (1954). In addition to sport hunting, large numbers were also captured for use both locally and abroad. Between 1863 and 1899, a total of 2,190 elephants were exported to foreign zoos in the USA and Europe (Clark, 1901). Furthermore, a large number of elephants were also dispatched to the princely courts in India (Marshall, 1846). It was the Government Ordinance in 1891 to prevent 'wanton destruction' of elephants that may have ensured the survival of the elephant.

*Corresponding author's email: charlessantiapillai@gmail.com 
During the period of the British rule from 1796 to 1948 , the population of elephants in the wild in Sri Lanka dropped from about 10,000 to 2,000 (Schultz, 1984), due partly to excessive hunting, but probably even more because of the loss of habitat when vast areas of forest in the hill country were clear-felled to make way for the establishment of coffee, and later, tea plantations. As a result, the elephant was virtually eliminated from the hill country and the low country wet zone, while those in the low country dry zone managed to survive. Today, the low country dry zone represents the last stronghold of the elephants in Sri Lanka.

Estimating the number of elephants in Sri Lanka has always been a difficult task. Elephants do not oblige the demographers by staying in one place. Much of the information currently available is based on speculation and educated guesswork. No one really knows exactly how many elephants were there in the wild in Sri Lanka about 200 years ago. The highest estimate of 10,000 elephants comes from the Administrative Reports of the Wild Life Department in 1953. The credit for emphasizing the need to place the management of elephants on sound science must certainly go to the Wildlife and Nature Protection Society, first established as Game Protection Society of Ceylon in 1894. The Society undertook an island-wide survey of elephants in 1958 beginning with the southern part of the island (Uragoda, 1994). The estimated population of elephants in the entire island of Sri Lanka was put between 1,600 and 1,700 (Norris, 1959). Subsequently, McKay (1973), suggested a minimum estimate for the total elephant population of Sri Lanka to be between 1,600 and 2,200 . It was the then leading conservationist with decades of experience of wildlife in Sri Lanka, Thilo Hoffmann who suggested that the Sri Lankan elephant population could be much larger than hitherto believed. According to him, the number of wild elephants in Sri Lanka could range between 4,000 and 6,000 (Hoffmann, 1975, 1978). Subsequently, A.B. Fernando from the Department of Wildlife Conservation estimated the population size of elephants to be anything between 2,800 and 3,250 and his estimate was used by Santiapillai and Jackson (1990) in 'The Asian Elephant: An Action Plan for its Conservation'. Subsequently, Kemf and Santiapillai (2000) quote an estimate from IUCN's Species Survival Commission's Asian Elephant Specialist Group that puts the number of elephants in Sri Lanka to be between 3,160 and 4,405 .
Numbers are not necessarily a safeguard against extinction (Jackson, 1982). Previous estimates of elephant numbers were just 'educated guesses' and so should be treated with caution. Nevertheless, as Caughley (1977) argues, in situations where an accurate estimate is not required, an educated guess from an experienced person thoroughly familiar with the animal and its habitat may serve as an estimate of density. Sometimes an informed guess may be closer to the truth than an estimate made indirectly from dung counts using untenable assumptions and unreliable data on defecation and decay rates. But as Caughley (1977) cautions, in most instances, guesses are guesses and we must not delude ourselves into believing that a casual familiarity with the animal or habitat gives anyone the monopoly on wisdom. Errors are likely to increase with the area surveyed and as Eltringham (1982) argues for small regions, the estimates are probably reasonably accurate. The problem with all these estimates of elephant abundance is that they were not based on any rigorous method that could be used by other researchers to study population trends. In the absence of a method, the population estimates cannot be compared to assess if the population has been expanding, declining or remaining stable.

The first attempt at transparency in estimating elephant numbers was in 1993 when the Department of Wildlife Conservation carried out a partial survey of wild elephants following the water-hole count method recommended by Sukumar et al., (1991). By pooling the maximum numbers of elephants that were recorded in just one day from the 153 observation points, a total of 1,967 elephants were estimated as the minimum number (Hendavitharana et al., 1994). Thereafter two more regional surveys were conducted; one in 2004 in the Northwestern Wildlife Region at which a minimum of 1,293 animals were recorded, and the other in 2008 in the Mahaweli Wildlife Region at which the estimated minimum number of elephants was 2,149 . The first true island-wide survey of wild elephants in Sri Lanka was carried out in August 2011 which provided a minimum estimate of 5,879 animals (Dissanayake et al., 2012; Santiapillai and Wijeyamohan, 2013).

The estimate of population size of the wild elephant in Sri Lanka that came about was a byproduct of the survey and not a raison d'etre for the exercise. Even though the method was not rigorous, given the objective, it proved adequate. There are those who would advocate using the indirect method of estimating elephant abundance 
based on dung counts. However, such a method would give only an estimate of elephant density and will not provide any information on population structure. Besides, there is no way of checking the accuracy of such a method. Furthermore, it is extremely time consuming, labor intensive, expensive, and likely to fail given the monsoonal pattern of rainfall Sri Lanka experiences. This is why the primary purpose of the national survey was to study the structure and composition of the elephant population by observing the animals in the wild. It was not a census designed merely to count elephants.

\section{REFERENCES}

Baker, S. (1853). The Rife and the Hound in Ceylon. Tisara Prakasakyo Press, Dehiwela.

Caughley, G. (1977). Analysis of Vertebrate Populations. John Wiley \& Sons. Chichester.

Clark, A.B. (1978). Sex ratio and local resource competition in a prosimian primate. Science 201: 163-165.

Deraniyagala, P. E. P. (1955). Some Extinct Elephants and Their Relatives, and the Two Living Species. National Museum of Ceylon, Colombo.

Dissanayake, S. R. B., Marasinghe, R., Amararathne, M., Wijeyamohan, S., Wijeyakoon, P. and Santiapillai, C. (2012). The First National Survey of Elephants in Sri Lanka. A report prepared for The Department of Wildlife Conservation.

Douglas-Hamilton, I. (1987). African elephants: population trends and their causes. Oryx 21: 11-24.

Eltringham, S. K. (1982). Elephants. Blanford Press, Poole. U.K.

Hendavitharana, W., Dissanayake, S., de Silva, M. and Santiapillai, C. (1994). The survey of elephants in Sri Lanka. Gajah, 12: 1-30

Hoffmann, T. W. (1975). Elephants in Sri Lanka, their number and distribution. Loris 13 (5): 278-280.

Hoffmann, T. W. (1978). Distribution of elephants in Sri Lanka. Loris 14 (6): 366-367

Jackson, P. (1982). The future of Elephants and Rhinos in Africa. Ambio 11 (4): 202-205.

Kemf, E. and Santiapillai, C. (2000) Asian Elephants in the Wild. 2000 A WWF Species Survival Report. WWF-International, Gland,
Switzerland.

Marshall, H. (1846). Ceylon: a general description of the island and its inhabitants. Tisara Prakasakyo Press, Dehiwela.

McKay, G.M. (1973). Behavior and Ecology of the Asiatic Elephant in Southeastern Ceylon. Smithsonian Contributions to Zoology 125: 1-113

Moss, C.J. (1988). Elephant Memories. William Morrow \& Co. New York.

Nicholas, C.W. (1954). The Ceylon elephant in antiquity. ii. The Portuguese, Dutch and British periods. The Ceylon Forester 1: 103111.

Norris, C.E. (1959). Preliminary Report on the Ceylon Elephant Field Survey. Wildlife Protection Society, Colombo.

Olivier, R.C.D. (1978). On the ecology of the Asian elephant. Unpublished $\mathrm{PhD}$ thesis, University of Cambridge, U.K.

Santiapillai, C. and Jackson, P. (1990). The Asian Elephant: An Action Plan for its Conservation. IUCN, Gland.

Santiapillai, C. and Wijeyamohan, S. (2003). Counting elephants in the wild. Gajah 22: 12.

Santiapillai, C. and Wijeyamohan, S. (2013). The First National Survey of Elephants in Sri Lanka. Current Science, 105 (2): 153-154.

Schultz, D. (1984). Another river dammed. Journey (Australasia Geographic Magazine) 68-79.

Sikes, S.K. (1971). The Natural History of the African Elephant. American Elsevier Publishing Co. Inc., New York.

Storey, H. (1907). Hunting and Shooting in Ceylon. Tisara Prakasakyo Press, Dehiwela.

Sukumar, R., Varman, K. S., Santosh, K. A and Ramakrishnan, U. (1991). Methods of estimating elephant numbers: a review. In Censusing Elephants in Forests. (Eds. U. Ramakrishnan, J.A. Santosh and R. Sukumar). pp. 2-29.Asian Elephant Conservation Centre, Bangalore, India

Tennent, J. E. (1967). The Wild Elephant and the Method of Capture and Taming it in Ceylon. Longmans, Green and Co. London. U.K.

Uragoda, C. G. (1994). Wildlife Conservation in Sri Lanka. Wildlife and Nature Protection Society of Sri Lanka. Colombo. 